\title{
THE GAZE
}

JOURNAL OF TOURISM AND HOSPITALITY

\section{Heritage Tourism in Japan and Nepal : A Study of Shikoku and Lumbini Him Lal Ghimire}

\author{
Board of Director, Rehdon College \\ drhimghimir@gmail.com
}

\begin{abstract}
Tourism, the world's largest industry, is essential to a community's economic vitality, sustainability and profitability. The word 'heritage' in its broader meaning is frequently associated with the word 'inheritance', that is, something transferred from one generation to another. Heritage might look old-after all, the language of heritage focuses on preservation, revitalization, and restoration-but closer inspection usually reveals contemporary concerns. Heritage is the symbolic embodiment of the past, reconstructed and reinterpreted in the collective memories and traditions of contemporary societies rather than being perceived as a mere apotheosis of bygone times. It is concerned with exploring both tangible and intangible remnants of the past. Important criterion for a designation as a World Cultural Heritage site is the "authenticity" and "sincerity" of a candidate site. The heritage sites are the most susceptible and vulnerable sectors. A large number of significant heritage sites around the world are fragile properties, and they are faced with different challenges. Both Japan and Nepal is home to a variety of frequently occurring disasters, which can cause wide-ranging damage to its cultural resources. Japan and Nepal's remarkable heritage is not only part of what makes both the countries a popular travel destination, but also something that needs to be properly protected, maintained and preserved, so that future generations can enjoy it as much as we do today. It has been interesting lesson to rest of the world that how Japan has been mitigating and surviving with large scale disasters. The Japanese culture, tradition and technology must have been playing significant role for this. The learning from Japan could be
\end{abstract}


instrumental to manage, rebuild and develop heritage sites and tourism in Nepal. This article is the partial outcome of my Postdoctoral research in Japan.

Keywords: Authenticity, preservation, revitalization, disasters, challenges and sustainability.

\section{Background}

Japan and Nepal have long history of cooperation and connection for the development of Nepal. Japan and Nepal's national identity tend to emphasize cultural values which often describe their people, traditions, customs, religion. Ekai Kawaguchi, a Buddhist monk known as an early explorer of Tibet, was the first Japanese visitor to Nepal. Kawaguchi came to Nepal in 1899 and a memento of Kawaguchi's Himalayan travels exists in Japan, in the Buddhist temple of Obaku-san Manpukuji on the outskirts of Kyoto. In 1912, he visited Lumbini on pilgrimage, accompanied by Prof. Junjiro Takakusu, Rev. Ryutai Hasebe, and others (Subedi, 1999; EJN, 2018).

The important events such as establishment of diplomatic relations between Japan and Nepal in 1956, successful conquest of Mt. Manaslu by the Japanese Expedition team in 1956, state and official visits of royal families of the both countries, establishment of Nepalese Embassy in Tokyo in 1965 and Japanese Embassy in Kathmandu in 1968 and many other events have contributed to develop tourism and attract Japanese tourists in Nepal. Takashi Miyahara, a mountaineer who came to Nepal first time in 1962, established the Hotel Everest View at 3,880 $\mathrm{m}$ in 1975. The iconic hotel became a model for foreign investment in Nepal's nascent tourism industry. He started Trans Himalayan Tours and introduced organized trekking to Japanese tourists. He also established Himalaya Hotel in Lalitpur and his next dream project Hotel Annapurna View in Sarangkot, Kaski is scheduled to open soon. Lumbini Hotel Kasai and Lumbini Hokke Hotel are also very nice hotels with Japanese investment in Nepal. Likewise, there are around 2500 Nepalese restaurants in Japan which are promoting and attracting Japanese tourists in Nepal.

Nepal Airlines Corporation (NAC) is preparing to resume its Japan service in September after a 10-year break with three weekly flights to Tokyo. Nepal and Japan had signed the ASA in 1993 and the national flag carrier launched its Japan service in 1994, flying to Osaka via Shanghai, China. In 2007, it was forced to suspend the route due to lack of aircraft. A Nepal Air Traffic Analysis conducted by Airbus in 2015 forecasted a traffic growth of 77 percent in five years from nearly 48,000 oneway travellers from Japan to Nepal. The country received 27,326 Japanese tourists last year. According to the Ministry of Foreign Affairs, the number of Nepalis living in Japan has swelled to more than 60,000. The Nepali community is the fifth largest foreign community in Japan (TKP, 2018). 


\section{Current situation of tourism in Japan and Nepal}

JNTO (2018) reveals that a record-breaking number of international visitors travelled to Japan in 2017. The country welcomed 28.7 million international visitors with a 20 percent increase on the previous year. The results from last year show that Japan is well on the way to achieving its goal of attracting 40 million visitors by 2020 , the year of the Tokyo Olympic and Paralympic Games. When the Visit Japan Campaign was launched in 2003, inbound tourists numbered 5.2 million. The campaign set out to increase the total to 10 million in seven years. MoCTCA (2018) writes year 2017 seems remarkable improvement in tourist arrivals. Tourist arrivals increased by 25 percent compared to 2016. Nepal welcomed 940218 tourists in 2017. Nepal is set to organize the year 2020 as Visit Nepal Year. It will be the third national level initiative to promote Nepal's tourism sector since the country first celebrated Visit Nepal Year in 1998 followed by the Nepal Tourism Year in 2011. It expects a growth of foreign tourists by 30 percent every year since 2018 to meet the target of 1.5 million tourists by 2020 . WTTC (2018) shows that the total contribution of travel and tourism to GDP was JPY37,135.9bn (USD331.2bn), 6.8\% of GDP, $6.4 \%$ of total employment $(4,171,500$ jobs) in Japan in 2017. Whereas the direct contribution of travel and tourism to GDP was NPR99.8bn (USD982.5mn), 4.0\% of total GDP, supported 497,500 jobs (3.2\% of total employment) in Nepal in 2017.

\section{Research and methodology}

Primarily, this paper is the partial outcome of my postdoctoral research on "Buddhist pilgrimage: Comparison of Shikoku, Japan and Lumbini, Nepal". Methodologically, this research is exploratory and analytical in nature. The research has adopted both qualitative and quantitative inquiries based on primary and secondary sources, and self-collected data. Primary data were obtained from field visits, questionnaire surveys and formal and informal interviews in Shikoku and the secondary data and information were collected from publications such as journals, books, documents and reports from the library; bulletin, reports, plans published by Government and non-Governmental organizations, different seminar papers; and Internet search.

There were three categories of respondents: Tourists/pilgrims visiting Shikoku, tourism service providing organizations/agencies (Hotels, travels, temples, restaurants etc.) and experts (writers/head of temples/CEO). I developed three sets of questionnaire both in English and Japanese languages and distributed the questionnaires in an envelope with stamp personally to the respondents so that they could return it by post or alternatively, could also send a scan copy of it by email. The questionnaire for pilgrims/tourist was posted on social sites as well. I have also used some of the data from my PhD research on "Pilgrimage Tourism: Special focus on Lumbini. 


\section{Heritage tourism}

Heritage tourism is concerned with exploring both material and immaterial, i.e., tangible and intangible remnants of the past (Kunwar \& Chand, 2016). Cultural heritage tourism (or heritage tourism) is a branch of tourism oriented towards the cultural heritage of the location where tourism is occurring. As per the National Trust for Historic Preservation, heritage tourism (sometimes called cultural heritage tourism) as "traveling to experience the places, artifacts and activities that authentically represent the stories and people of the past and present. It includes cultural, historic and natural resources." Timothy (2011; in Kunwar \& Chand, 2016) states that heritage tourism is highly inclusive- probably the most encompassing type of tourism yet to be identified. It revolves directly around living cultures, the built environment, faith, traditions, folklore, arts and handicrafts, music and the everyday life of people.

Tourism, the world's largest industry, is essential to a community's economic vitality, sustainability, and profitability. More than simply visiting historic sites, heritage tourism is a personal encounter with traditions, history, and culture. Heritage tourism is based upon the concept that each community has a story to tell. This is a rapidly growing niche market that is directed towards experiencing the local customs, traditions, arts, history, sites, and culture that authentically represent a particular place. To the heritage tourist, this culture must be unique and it must be authentic (Speno, 2010). What makes the sites or toured objects authentic? Authenticity is conventionally defined as originality, genuineness or sincerity.

World Heritage, linked to global power, impacts powerfully on the tourist gaze directed to landscapes and tourists' senses of place. The most important criterion for a designation as a World Cultural Heritage site is the "authenticity" and "sincerity" of a candidate site, which are necessarily demonstrated as an exemplification of national properties. The local authorities are proud that their authentic sites have been designated as World Heritage. They often speak about the "world" or the "global." (Yasuda, 2010). Heritage, as Hoelscher (2006) states, "is not merely a way of looking at the past, but a force of the present that affects the future." Park (2014; in Kunwar \& Chand, 2016)) views heritage as a symbolic embodiment of the past, reconstructed and reinterpreted in the collective memories and traditions of contemporary societies rather than being perceived as a mere apotheosis of bygone times. Heritage is culturally ascribed and socially constructed and is a flexible concept where heritage today, is related with the increasing contemporary use of the past, as manifested in the popularity of a 'heritage industry'. Heritage tourism is becoming an increasingly significant component of the global tourism industry and the growth of the heritage industry has undoubtedly contributed to expanding the scope and appeal of heritage. Pedersen (2002) writes that the commodification 
in heritage has led to creating and fabricating a new environment in which different possibilities and potentials of heritage can coexist for different audience. Within the context of tourism development, heritage often becomes a commercially driven entity that is carefully selected, packaged and promoted. Heritage tourism is a broad category that embraces both eco-tourism and cultural tourism, with an emphasis on conserving natural and cultural heritage. It is a category or market segment that includes visits to historic sites, museums and art galleries, and exploring national and forest parks. Heritage tourism, because of the large number of activities it covers, is difficult to define and measure. In recent years, city planners interested in urban regeneration have adopted the term to describe many tourism programmes, a strategy that has received support from business and banks. Garrod \& Fyall (2000) surprising inscribes that the heritage tourism sector has received relatively little attention from scholars interested in the concept of sustainable tourism. A little academic attention has been paid to exploring the relationship between heritage tourism and sustainability because the two concepts evidently share a common theme. Yet the heritage sector represents a highly significant component of tourism in many developed economies.

Cultural heritage holds great importance for communities around the world. Heritage connects us to the past and provides invaluable insights into our identities and evolution. It can play an important role in economic growth, poverty reduction, and sustainable development (WBG, 2017). The former includes built heritage such as religious buildings, museums, monuments, and archaeological sites, as well as movable heritage such as works of art and manuscripts. Intangible cultural heritage includes customs, music, fashion and other traditions within a particular culture. Cultural heritage tourism defined as travel concerned with experiencing the visual and performing arts, heritage buildings, areas, landscapes, and special lifestyles, values, traditions and events has become a major force in the tourism industry. It includes handicrafts, language, gastronomy, art and music, architecture, sense of place, historic sites, festivals and events, heritage resources, the nature of the work environment and technology, religion, education, and dress. Cultural heritage tourism brings together the accepted practices of research, site development, design, planning, construction, preservation technology, interpretation, and visitor services and connects them to the practice of tourism in marketing, research, product development, and promotion. It integrates tourism planning and development practices into the heritage resource management process. Within the planning process it is important to note that cultural tourism may take many forms. (Jamieson, 1998). The conservation community, as well as tourism interests, should have a long- term view in planning and heritage resource protection if resources are to be conserved for future generations. 


\section{Heritages of Japan}

Religion and culture in Japan reflects a long history during which various religious beliefs and practices - some indigenous, some "imported" from other places - have been adopted and adapted to Japanese culture. The ancient indigenous folk religion, later formalized as Shinto, was based on feelings of awe toward the sacred powers (kami) that brought life to the earth and human community. According to Nihon Shoki (the Chronicles of Japan), Buddhism was introduced to Japan in 552 AD by Korean monks. Sutras were later brought from China, temples and shrines were built and monastic communities established. Both Confucianism and Taoism migrated to Japan, impacting Japanese culture, religion, philosophy, and politics. Japanese religion adopted Chinese Buddhist rituals, Taoist story-telling and divination, as well as Confucian concepts of piety and ancestor veneration. Pure Land, Zen, and Nichiren Buddhism all developed in Japan, with the Nichiren School taking on a uniquely Japanese character.

The Japanese perception of World Heritage is related to their admiration of Western culture and its hegemonic power. Therefore, Japanese autonomous bodies enthusiastically want their sites to be designated as World Heritage site, associating with Western aesthetics. The terms, "world" and "global" are synonyms for the terms, "Western" and "Europe" for the Japanese. The designation of the World Heritage indicates that the site is highly valued by Western society. The Japanese attempt to purchase the World Heritage of a global cultural brand as cultural capital even though they spend enormous amounts of money on it. Thus, World Heritage works as an agency of Western culture promoting cultural imperialism, at least in Japan (Yasuda, 2010). With its long history, traditional culture and beautiful nature, Japan has twentytwo locations/properties inscribed on the World Heritage Sites (UNESCO, 2018).

\section{Heritages of Nepal}

Nepal, the Himalayan country situated between China and India steeped in several unique cultures, legends and myths. A beautiful, awe-inspiring land, Nepal is the birthplace of Buddha, the country with the Mount Everest and home to the Kumāri: the living goddesses. Nepal has a unique and diverse living history and culture. It has been blending and carrying the history of thousands of years (Ghimire, 2017). The culture, festivals, traditions, rituals, legends, temples, monasteries, stupas, religious books, archeological remains, structures, caste/ethnic groups and the welcoming nature of Nepalese people are more than enough to prove its authenticity (Kunwar \& Ghimire, 2012). The unique and diverse Nepalese culture has been the attraction for rest of the world. UNESCO has listed four World Heritage Sites in Nepal. Two cultural sites are: Kathmandu Valley which is connected and combined with seven other sites (Durbar Squares of Hanuman Dhoka (Kathmandu), Patan and Bhaktapur, 
the Buddhist stupas: Swayambhu and Bauddhanath and the Hindu temples: Pashupati and Changu Narayan; and Lumbini, the Birthplace of the Lord Buddha. Two natural sites are: Chitwan National Park and Sagarmatha National Park.

\section{Disaster and heritage sites}

World Heritage properties and heritage sites in general are exposed to the impacts of natural and man-triggered catastrophic events, which threaten their integrity and may compromise their value. The heritage sites are the most susceptible and vulnerable sectors. A large number of significant heritage sites around the world are fragile properties, and they are faced with different challenges. Cultural heritage is always under pressure from a variety of risks. Risks to heritage sites are dependent on the nature, specific characteristics, inherent vulnerability and geographical environment of the site. The loss or deterioration of these outstanding properties has severely negative impacts on local and national communities, because of their cultural importance and socio-economic value. Cultural heritage is increasingly exposed to disasters caused by natural and human induced hazards. Natural disasters are escalating from the local level to the national level and the global level, such as tornado, sudden torrential rain, typhoons, storms, in-land earthquake, volcanic eruptions, sea-trench earthquake, and so on. They are becoming more frequent, larger, more wide spread, more diverse, more complex and more difficult to predict. Prevention and mitigation of disaster damage can be a role that World Cultural Heritage and World Natural Heritage can adopt. Natural disasters such as volcanic eruption, earthquake, tsunami, tornado and typhoons damage people's lives and also ecosystems. They are natural phenomena, but human elements and social factors are also important. Prevention, recovery and restoration from natural disasters provide opportunities for us to explore new possibilities for the conservation and promotion of World Heritage sites (Sugio, 2015).

Both Japan and Nepal is home to a variety of frequently occurring disasters, which can cause wide-ranging damage to its cultural resources. For this reason, the country has taken specialized measures in establishing a disaster risk management system and methodology for post-disaster emergency response and recovery. Shuri Castle, a palace of the Ryukyu Kingdom first built in the 14th century, was destroyed during the Battle of Okinawa in the World War II. The Japanese forces had set up a defense perimeter which goes through the underground of the castle. U.S. military targeted this location by shelling with the battleship USS Mississippi (BB-41) for three days in May 1945. The castle burned down subsequently after. It was later reconstructed in the 1990s. Kinkaku-ji (Golden Pavilion) of Kyoto, Japan was burnt down by an arsonist in 1950, but was restored in 1955 (Wikipedia, 2018). When a powerful earthquake struck East Japan in March 2011, more than 700 national landmarks were damaged by the earthquake, most located in the Tōhoku and Kantō regions. In addition to these sites, many other traditional buildings and historic townscapes were damaged 
in places such as the coastal city of Kesennuma in the Tohoku region. The repair and restoration of built heritage has proved to be an important social element for communities recovering from disaster. Local authorities in Japan have prioritized the needs of different sites and communities affected by the earthquake. The work in affected area aimed to help reinvigorate the local economy and boost town morale by rebuilding the tourist economy. The ecosystems characteristics of Japan are important elements of World Natural Heritage sites. Damage due to the rapid increase in the population of deer since around 1990 is spreading. Deer eat the lower parts of trees and once their favorite plants have disappeared, they eat trees that they do not usually prefer. As a result, only the bare ground remains. The soil is washed away, and the forest is destroyed. Conflicts with human activities and damage to agriculture and forestry from deer impact have exceeded the tolerable limit of local economies in many places. Furthermore, there are concerns about the survival of rare plants and the possibility of reduced forest renewal (Sugio, 2015:749).

Nepal offers a vivid example of the human and economic toll arising from the impact of disasters on cultural heritage (WBG, 2017). The damage and negative impacts of devastating earthquakes on April 25, 2015 and its aftershocks were significantly large in the history of Nepal. There had been "extensive and irreversible damage" at the world heritage site in the Kathmandu valley, the capital city of Nepal. The earthquake affected about 2,900 heritage structures with cultural and religious values. World Heritage Monument Zones were severely damaged and many collapsed completely. The earthquake's impact on heritage places was extensive throughout the Kathmandu valley, which is home to hundreds of sacred Buddhist and Hindu sites. The three urban zones at the site are Durbar squares - meaning "noble courts" - in the settlements of Kathmandu, Bhaktapur and Patan. These three complexes as "almost fully destroyed". The four other zones are religious sites: Buddhist stupas (monuments) at Swayambhunath and Boudhanath. Hindu temple complexes at Pashupatinath and Changu Narayan were also damaged. The Durbar Square is a mesh of palaces, courtyards and temples. UNESCO calls it "the social, religious and urban focal point" of the Nepalese capital. Basantapur Durbar Square was the residence of Nepal's royal family until the 19th century. Amongst the most immediately noticeable losses is the toppling of the Dharahara Tower, a nine story tower that offered visitors who braved its spiral staircase a magnificent view of Kathmandu. Even after more than three years, the temples and palaces at the world's largest concentration of UNESCO World Heritage Sites remain heaps of rubble, other structures that had suffered seismic damage were still being propped up by wooden beams, but a very little reconstruction has taken place. The earthquake-damaged world heritage sites in Kathmandu Valley are at risk of being put on the UNESCO list of World Heritage in Danger if they are not renovated/preserved within a given time (Ghimire, 2016). 
Cultural heritage is vulnerable to the adverse impacts of natural disasters. Floods, earthquakes, landslides, fires, long-term climate effects, and other natural hazards can cause damage or even total destruction of cultural heritage. In part, the vulnerability of heritage assets relates to their location and physical characteristics, including quality of construction and conservation. Urbanization and agglomeration of economic activity have created situations in which historic heritage assets-including monuments, places of worship, or natural heritage-find themselves surrounded by new construction activity in which the work is done poorly and without an authorizing legal framework that takes proximity to heritage sites into account. Unlike disaster damage to regular infrastructure, disaster damage to cultural heritage is often irreversible; in addition to economic losses and livelihoods impacts (WBG, 2017).

\section{Pilgrimage in Shikoku}

Pilgrimage has been one of the important aspects of the Japanese culture and heritage tourism in Japan. Pilgrimage in Japan had developed gradually. The ascetic wanderings of individuals took the form of pilgrimage routes, which were then adopted by the aristocracy and, later, the common masses. Pilgrimage became popular in the Heian period among the aristocracy, who visited places like Ise Shrine, Hasedera and Shitennoji. During the Edo period, pilgrimage became popular for all classes of people (Kodansha, 1983). Shinno Toshikazu has described pilgrimage as "one of the great pillars" of Japanese religion. Pilgrimages are important in Japanese religious development, and play specific and crucial roles within the functioning of the various religious organizations with which they are associated, it has been voluntary pilgrimages such as the Ise pilgrimage and multiple-site types such as the Saikoku junrei, the Shikoku henro, and the various regional "copied" pilgrimages, that have tended to attract the greatest levels of mass participation and to have had the greatest influence in the broader development of Japanese pilgrimage culture. It is these pilgrimages in particular that are focused on in this volume, and it is to these, and the typological differentiations that may be made between them, that we now turn (Reader \& Swanson, 1997: 238). In Japan, pilgrimages can be classified into two general types: (1) multi-site circuits and (2) single-site pilgrimages. Multisite circuits involve a number of sacred places linked together numerically, with each location devoted to the same single deity or to a group of related deities. This is known as honzon junrei. Single-site pilgrimages involve a journey to one particular sacred site. There are a number of aspects of the pilgrimage which are rich in symbolism - particularly its association with death. The clothing worn and items carried by a pilgrim indicate that he or she is 'dead to the world' (Reader, 1993: 107; in MacGregor, 2002: 11). What attracted pilgrims were temples known for their miracle efficacy, in other words miracle temples in Japan. Kannon was clearly the most popular deity venerated at these miracle temples. Furthermore, the 
most popular pilgrimage temples belonged to three sects in Japan: Tendai, hmgon, and Hosso (Ambros, 1997: 304).

Schumacher (2013) writes pilgrimages were first undertaken in the Nara Period (710-794 AD), but the custom did not become popular until the Heian Era (7941185 AD). Kumano, in southern Wakayama Prefecture, became a large center for adherents and pilgrims of the Shugendo Sect during the Heian Period. Other popular pilgrimages at the time were to Hasedera (Kyoto), Shitenno-ji (Osaka), and Mt. Koya. In the Edo Period (1600-1868 AD) the number of people making pilgrimages to both Buddhist temples and Shinto shrines increased rapidly, especially to Ise Shrine, Kotohira Shrine (Kagawa), the 88 temples of Shikoku and Western Japan, to Zenkoji (Nagano), Kiso Ontake (Nagoya), and Mt. Fuji (Shizuoka). One phenomenon of the Edo era was Okage Mairi - the special pilgrimage to the Ise Jingu Shrine. The Okage Mairi tradition continues unabated even today, with approximately six million people visiting Ise Jingu Jingu yearly. In Japan, as Pye (2014) writes that pilgrimages have been turned into considerably less arduous ordeals than they were in the past thanks to public transport, comfortable lodgings, good food and an ample supply of vending machines. Reader (2005) elicits that the henro was one of several pilgrimages that emerged in the latter Heian period linked to the activities of religious mendicants and wandering proselytizers known as hijiri, whose seminal role in popularizing folk Buddhist faith in Japan has been widely discussed by Japanese scholars. The hijiri promoted the virtues of Buddhist figures of worship and emphasized pilgrimages to important temples and other holy places as a way of deepening faith, attaining salvation in this or the next life, and gaining merit and worldly benefits (107). Likewise, Shinnen was the seminal figure in the development of the henro, making the pilgrimage more widely known through his stones, guidebooks, and miracle tales. It is a striking example of how individuals can help make the pilgrimage and create a series of footsteps for others to follow (121).

"Sacred Sites and Pilgrimage Routes in the Kii Mountain Range" is one of the important World Heritage sites in Japan. Sacred Sites in the Kii Mountain Range consist of Kumano Sanzan, Yoshino, Ohgake, and Koyasan, and are the religious amalgamation of Shinto, Buddhism, and Shugendo. The Sacred Sites have attracted a large number of pilgrims from all over Japan. In particular, the Kumano area is considered to be a heritage site as it is deeply associated with the creation myth of Japan. Kumano Kodo are pilgrimage routes for Kumano Sanzan (three shrines). There are primarily four routes, Koheji, Nakaheji, Oheji, and Iseji, which are accessible from various areas. Kumano Moude (pilgrimage) began in the middle of the Heian era $\left(10^{\text {th }}\right.$ century). Kumano Sanzan was regarded as a heaven, and emperors and aristocrats often went on a pilgrimage wishing for a cure for illness or for material benefits. The whole Kumano area was regarded as another world. Therefore, Kumano 
is a mythical place representing Japanese cosmology. Emperor Uda began Kumano Moude (pilgrimage) for the first time in 907, and Emperor Shirakawa popularized it. (Yasuda, 2010). The Shikoku pilgrimage is the most famous type of pilgrimage and most frequently referred to as henro a term specific to this pilgrimage or meguri, which literally means 'to go round,' but 'is most widely used in cases where the sites on a pilgrimage route are not united by their dedication to a single figure of worship', (Reader \& Swanson, 1997: 233). Perhaps the most famous pilgrimage in Japan -around the island of Shikoku - appears in chronicles of the Heian era (latter half of the eleventh century), when it developed as an ascetic practice involving religious sites. By the seventeenth century a more structured route had developed, involving the eighty-eight temples still visited today. It seems that, in the latter part of the Muromachi period (1338-1573), the trip to Shikoku became "a widespread practice involving participants other than religious specialists and ascetics" (Reader 1987: 116). Statler, (1983: 97) notes the Japanese people are an optimistic. In Japan, over the centuries, Buddhism was transformed into an optimistic creed. Kobo Daishi's contribution to this was his insistence that man and women too, for whom earlier Buddhism held out no hope had within him the seed of Buddha; by hard practice following strict precepts anyone could find and nurture that seed, could manifest his innate Buddha nature -could achieve enlightenment. In pilgrimage typologies developed by Japanese scholars, Shikoku is classified as a seiseki pilgrimage- one associated with the sacred traces or presence of a holy person. In Shikoku this figure is Kobo Daishi, a miracle-working figure with origins in the Japanese Buddhist tradition whose presence permeates the pilgrimage and binds it to the island of Shikoku (Reader, 2005: 10).

The beginnings of the Shikoku pilgrimage are said to date back to the ninth century when the Buddhist priest Kukai, later known as Kobo Daishi (774-835), made a journey around the Shikoku Island in search of enlightenment. Kukai developed the Shikoku pilgrimage route comprising of 88 main Buddhist temples and numerous additional temples and shrines with several ancient local pilgrimages. By the 17th century, the fame of the henro had spread, and become popular among ordinary Japanese. Iannarone (2013) writes Kobo Daishi, founder of the Shingon sect of Buddhism, is one of the most important people in Japanese history, and he still holds considerable sway and respect in Japan today. Aside from being a priest, he was also a master calligrapher, poet, scholar and advisor to the emperor. In his early years, he turned away from his aristocratic upbringing and became a wandering ascetic in the mountains and valleys of Shikoku; the 88 temple pilgrimage recreates his journeys around the island.

The Shikoku Eighty-Eight Sacred Places Pilgrimage is the most famous type of pilgrimage. It is one of the most prominent, evocative and photogenic pilgrimages in 
Japan with a highly developed pilgrimage culture which is one of the most prominent elements in Japanese religious structure (Reader, 2005: 9). The Shikoku pilgrimage has become an international pilgrimage destination. People with other religious faiths than Buddhism also make pilgrimage in Shikoku.

Figure 1: Shikoku Island and location map of 88 temples

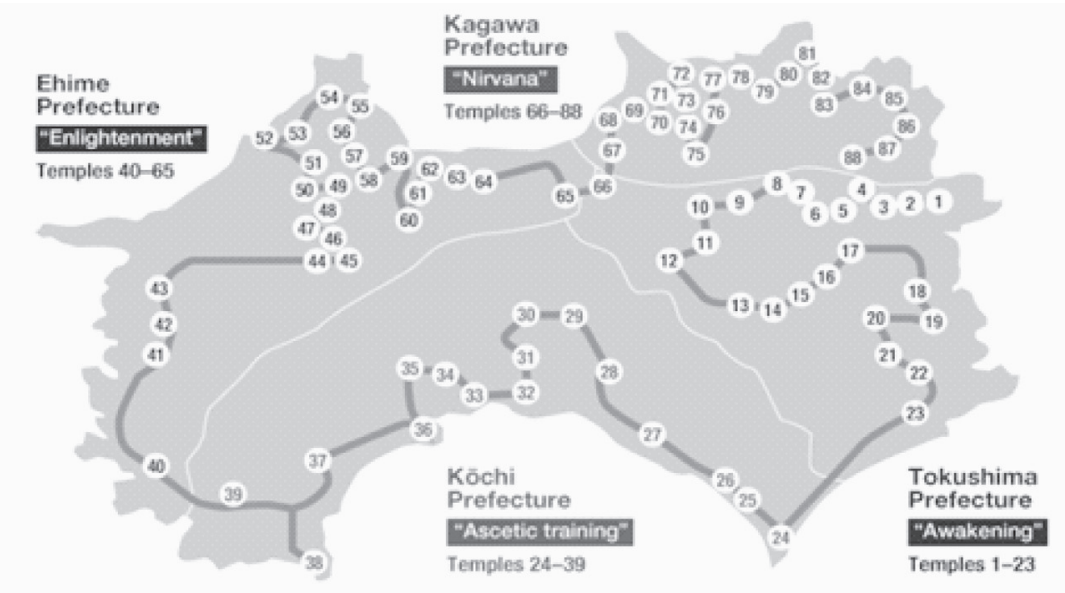

Geographically, Shikoku is one of the four main islands of Japan. It is located in the southwestern part of the Japanese archipelago at latitude of $34^{\circ} \mathrm{N}$. Shikoku is comprised of four prefectures, Tokushima, Kagawa, Ehime and Kochi. Shikoku has a mild and warm climate with successive seasonal beauty.

\section{Henro and numbering of temples}

One of the standard Japanese words for pilgrimage is junrei. However, the Shikoku pilgrimage is called henro. Shikoku literally means "four provinces" and the pilgrim's journey through the four provinces is considered to be a symbolic path to enlightenment. The theme of Tokushima prefecture (temples 1-23) is Awakening; Kōchi prefecture (temples 24-39) is Ascetic training; Ehime prefecture (temples 40-65) is Enlightenment; and Kagawa prefecture (temples 66-88) is Nirvana. Since pilgrims have to visit all eighty-eight temples to complete the pilgrimage, all of them are equal; however, some may be more equal than others in the eyes of the pilgrims. Temples with dramatic physical settings or with powerful historical connections tend to have a greater effect on pilgrims.

\section{Ohenro practices at temples}

Mostly, the pilgrimage starts from Ryōzenji (Temple No. 1) in Tokushima and ends at Ökuboji (Temple No. 88) in Kagawa. The pilgrims are given the Buddhist Ten Commandments to follow at least during the pilgrimages at temple number one. These are: Do not kill. Do not steal. Do not commit adultery. Do not tell a lie. Do not 
use flowery language. Do not speak ill of others. Do not be double-tongued. Do not be covetous. Do not be angry. Do not be perverse.

Traditionally, the pilgrims (O-henro) perform the following optional actions at each temple in Shikoku:

- At the main gate: To ward off evil spirits, the pilgrims bow once facing the main hall.

- At the wash basin: To purify themselves, pilgrims wash their hands and mouth.

- At the bell tower: Pilgrims ring the bell to mark their arrival.

- At the main hall: The main deity can be seen here. First, pilgrims light incense and a candle, ring the bell once, and declare to the main deity that they have come to worship. Drop the name-slip (osame-fuda) and copied sutra (shakyō) in the box, recite the sutras.

- At the Daishi hall: A figure of Kōbō Daishi can be seen here. Pilgrims worship in the same way as at the main hall.

- At the Stamp Office: Pilgrims receive the temple stamp in their stamp book.

- At the main gate: Pilgrims again face the main gate and bow once

\section{Shikoku Ohenro costumes}

O-henro are free to wear whatever they please on their pilgrimage. However, the pilgrim's traditional costume (special symbolic clothing) comprises a white shirt with Japanese script indicating they are a pilgrim, a conical sedge Chinese hat, a shoulder bag, and a walking stick. By choosing these items, one will be identified and respected as a pilgrim by those one meets along the way. Foreign pilgrims gain a sense of belonging to a privileged group in Shikoku. Once you start walking in the white $\mathrm{O}$-henro costume, you are no longer treated as a foreigner but as an O-henrosan like everybody else. It is really a unique experience that you cannot experience anywhere else. O-henro do indeed cross boundaries of language, culture, and nationality (Moreton 2016). On the other hand, pilgrims-in a vehicle or on footconsider themselves to be traveling alone with Kōbō Daishi as their companion and guide. This spiritual presence is expressed by the words dōgyō ninin (two traveling together) written on the hats. The temperature and weather of mid-March to May in spring, and October to November in autumn, are most suitable for undertaking the pilgrimage in Shikoku. In the normal cycle of yearly weather, during the rainy season of June and July, there is a lot of rain. In August and September the weather is stable, but this is the season when occasional typhoons will make their appearance. Reader $(2005,1)$ writes that there is a Japanese saying that in spring Shikoku comes alive 
with the sound of pilgrims' bells. The trail itself is very well marked by the ubiquitous red arrows and other markers that populate the trail. There are many ways to do the Shikoku pilgrimage. Everyone has their own personal circumstances, such as the ability to walk, paying capacity, time availability, interest, and so forth.

Table 1: Basic Cost for Pilgrimage in Shikoku

\begin{tabular}{|l|l|l|}
\hline Pilgrimage option & Days & Tentative cost \\
\hline $\begin{array}{l}\text { Walking entire pilgrimage at one } \\
\text { time }\end{array}$ & $45-60$ days & $¥ 400,000$ (less than ¥10,000/day) \\
\hline Bicycle pilgrimage & $15-20$ days & $¥ 200,000$ (At least) \\
\hline $\begin{array}{l}\text { Small groups (charter small bus- } \\
\text { ses or taxis) }\end{array}$ & 8 days & $¥ 500,000$ (At least) \\
\hline Tourist bus tours & 9 -12 days & $¥ 225,000$ - $¥ 250,000$ \\
\hline
\end{tabular}

\section{Lumbini: An international pilgrimage destination}

Lumbini hallowed by the birth of the Sakyamuni Buddha, one of the most significant pilgrimage destinations in the world lies in the southwestern plains of Nepal. Nepal is honored to have on its territory Lumbini (Kunwar \& Ghimire, 2012), the birthplace Lord Buddha, the greatest, the brightest, and the light of peace and indeed the most illustrious son of Nepal (Guruge, 1998: 26). The newly born Prince Siddhartha (who later distinguished as Lord Buddha) took his seven steps and uttered an epoch-making message to the suffering humanity in Lumbini. The famous Indian Maurya Emperor Asoka guided by his spiritual teacher Upagupta made a pilgrimage visit to this holy site in 249 B.C. Famous Chinese pilgrims Tseng Tsai (4th century), Fa-Hsien (5th century) and Hiuen-Tsang (7th century) visited Lumbini for pilgrimage and study about Buddhism and spirituality. The visits of the Chinese travelers brought more records out about Lumbini. Hiuen Tsang's records are the most informative of all for he not only traveled to see Lumbini and other Buddhist sites, but he also maintained a detailed description of his travel. UN Secretary General U Thant's pilgrimage to Lumbini in 1967 was taken as milestone in the history of Lumbini. The historic events held in Lumbini reconfirmed and enhanced Lumbinis status as the Fountain of World Peace and sacred pilgrimage shrine of the Buddhists and peace-loving people and a symbol of international brotherhood, peace and prosperity, and helped to project it as a World Peace City and important touristic destination in the world. Geographically; Lumbini, the birthplace of Lord Buddha which has been internationally recognized, is situated in Rupandehi District of Southern Terai at an altitude of $105 \mathrm{~m}$ above the sea level and around $300 \mathrm{Km}$ southwest of Kathmandu-the capital of Nepal. 
After the parinirvana (physical death) of the Buddha, the relics of His body were collected from the funeral pyre and divided into eight parts. These were distributed to the claimants and stupas, were erected on the relics. The practice of pilgrimage in Buddhism probably started with visits to these places, and the purpose could be to achieve personal advantages such as rebirth in a good location, as well as to honour the great master. Thus the custom of pilgrimage has been widespread among Buddhist for many centuries. Buddha had emphasized about the importance of pilgrimage (Buddhanet, 2010). The Buddha advises for pilgrimage without which there is no release from grief and unless the end of the world is to be reached. So let a man be a world-knower, wise, world-ender (Kunwar, 2006). It was the Buddha himself who enshrined pilgrimage as an important act in the life of a practitioner. In answer to Venerable Ananda's concern that the monks would no longer be able to see the Buddha and pay their respects after His Mahaparinirbana, the Buddha mentioned four places which a pious disciple should visit and look upon with feelings of reverence. They are:

- Lumbini: "Here the Tathagata (the Buddha) was born!

- Buddhagaya: "Here the Tathagata became fully enlightened, in unsurpassed, Supreme Enlightenment!

- Sarnath: "Here the Tathagata set rolling the unexcelled Wheel of the Law!

- Kusinagara: "Here the Tathagata passed away into Nirvana.

In visiting those places, early Buddhist pilgrims not only walked in the Buddha's footsteps, thereby metaphorically treading the same path to enlightenment while being in his presence, but did so alongside fellow pilgrims walking the same path and hence experienced a sense of community. Pilgrimage has been especially conducive concept as its focus on the notion of life as a journey toward higher goals and because of its emphasis on transience in Buddhist tradition. The Buddha was the first Buddhist pilgrim, and his life story is one of pilgrimage, in which he leaves home to travel in search of the truth. Indeed, key places associated with his life and significant turning points in Buddhist history (Reader, 2012). Furthermore, the Buddha said, "And whosoever, Ananda, should die on such a pilgrimage, with his heart established in faith, he at the breaking up of the body, after death, will be reborn in a realm of heavenly happiness" (Mahaparinirbana Sutra Chapter V; in San, 2002: 15). There are other important sites as well where the Buddha performed his great miracles and those where he and the sangha held their rain retreats.

Pilgrimage to the holy places mentioned by the Buddha is a once-a-lifetime undertaking by Buddhists. A pilgrimage is a journey to a sacred place as an act of devotion and faith (shraddha). A strong desire stems from one's devotion to undertake a pilgrimage in order to heed the Buddha's advice. In the course of visiting the sacred 
places, pilgrims feel the need to be in the Master's presence and this fullness of faith conduces to joy and the observance of morality and the foundation of all merit. After the journey is over, one should always try to recollect the joyful moments spent at holy places to keep them vivid in one's memory (San, 2002: 11). Reader (2012) writes that as Buddhism spread across Asia, it also created new places of pilgrimage in every region that Buddhism permeated - from sacred mountain sites in Tibet to places such as the Shwe Dagon Temple in the Burmese capital of Rangoon, which according to popular belief houses relics of the Buddha's hair, and the Temple of Tooth in Kandy, Sri Lanka, which also houses a reputed relic of the Buddha. In such places, it was believed; pilgrims could thus "meet" the holy figure at the center of their religion and acquire his spiritual grace.

The grove of Lumbini changed into a pilgrimage site soon after the parinirvana (physical death) of the Buddha. Lumbini's strengths in this respect are - to name just a few - that it is a top class pilgrimage site, declared as World Peace City, a World Heritage Site and hailed as the Fountain of World Peace that may provide ultimate peace and nirvana. It hosts national and international Buddhist monasteries and therefore, is the home of monks, nuns, peace lovers, and spiritual leaders. There are more than 160 religious, historical and archaeological sites related to the Buddha and his life in and around. The importance of Lumbini is so great that the Buddha himself advised his followers to make the pilgrimage to Lumbini. Lord Buddha explained the significance of Lumbini in the words: "Lumbini should be (visited) seen by person of devotion, and which would cause awareness and apprehension of the nature of impermanence ....." because Lumbini is the foremost Buddhist pilgrimage site in relationship to the other sacred sites. Many scholars designate Lumbini as an unmatched spiritual destination of the Buddhist world. The visitors are overwhelmed with the sanctity and serenity of Lumbini. The spiritual feeling of being at the holy birthplace of the Enlightened One nurtures devotion and faith in their mind and fills their heart with purity, compassion and wisdom (Ghimire, 2013).

Spirituality and peace are the fundamental aspect of Buddhism and it should exist at Lumbini. The Lumbini region encompasses dozens of Buddhist-spiritual sites and houses beautiful flora and fauna which can evoke spirituality, serenity and satisfaction in the mind of visitors. Lumbini, the world heritage site with outstanding universal value has great importance to be one of the top class spiritual and pilgrimage destinations in the world (Ghimire \& Rai, 2015). Pilgrims and visitors come to Lumbini and express their religious and spiritual sentiments in various ways, often linked to their diverse cultures. They come to meditate, chant, and beat on drums, offer gold leaves, offer coins, incense or milk. They all come with the expectations of peace and harmony (UNESCO, 2013:11). The spiritual feeling of being at the holy birthplace of the Enlightened One nurtures devotion and faith in their mind and fills their heart 
with purity, compassion and wisdom. Today, Buddhists from all over the world, as well as other travelers, are interested in the ancient history and culture of Nepal.

\section{Shikoku survey findings}

In this section, an attempt has been made to present the results of some of the primary data collected from Shikoku analytically. Various methods of presentation have been used to illustrate and present data.

Purpose of visit in Shikoku: The purpose of visit could be one of the motivating factors for travel that makes tourists move away from their home to a desired destination. An inquiry was made to know the purpose of visit of the respondents. Tourists/pilgrims visit Shikoku with various purposes. In the multiple response question, survey participants could respond to more than one purpose. As can be seen, $85.3 \%$ visited Shikoku for pilgrimage whereas $21.6 \%$ visited Shikoku for sightseeing, and so on. It shows that Shikoku is an important sightseeing destination as well.

Furthermore, an attempt was made to see the cross-tabulation between the nationality and purpose of visit of the respondents in Shikoku. The result shows that $87.7 \%$ of Japanese visited for pilgrimage and $80.0 \%$ of Canadians visited for sightseeing. Likewise, the cross-tabulation between sex, age group, religion, and purpose of visit shows that $92.4 \%$ Buddhists, $75 \%$ Christian, $100 \%$ Shintoists, $100 \%$ Hindus, and $75.9 \%$ of those of other religions visited for the purpose of pilgrimage. It shows that quite large numbers of people with other religious faiths

Table 2: Multiple Responses on Purpose of Visit

\begin{tabular}{|c|c|c|c|}
\hline \multirow{2}{*}{$\begin{array}{c}\text { Purpose of } \\
\text { visit }\end{array}$} & \multicolumn{2}{|c|}{ Responses } & \multirow{2}{*}{$\begin{array}{l}\text { Percentage } \\
\text { of Cases }^{* *}\end{array}$} \\
\hline & $\mathbf{N}$ & Percentage $^{\star}$ & \\
\hline Pilgrimage & 99 & $73.3 \%$ & $85.3 \%$ \\
\hline Sightseeing & 25 & $18.5 \%$ & $21.6 \%$ \\
\hline Research & 2 & $1.5 \%$ & $1.7 \%$ \\
\hline Others & 9 & $6.7 \%$ & $7.8 \%$ \\
\hline Total & 135 & $100.0 \%$ & $116.4 \%$ \\
\hline
\end{tabular}
than Buddhism also participated in the pilgrimage in Shikoku.

Influencing factor to visit Shikoku: There are various factors influencing pilgrims/ tourists to visit Shikoku. The most influential factors are religious belief and respect for Kōbō Daishi, to honor and remember the ancestors, participation in rituals, to gain a sense of Buddhism and Japanese culture, information from books and other publications, friends, yoga teachers, travel agents, websites, advertisements, natural beauty, and hiking outdoors. One pilgrim was influenced by previous visits ( $\mathrm{p}-21)$; another pilgrim found a picture of Shikoku pilgrimage on Santiago's way (p-15). One 
met a Japanese pilgrim who talked about Shikoku while walking Camino; others love walking on pilgrimages and the spiritual experience (p-78). One heard the voice of the Buddha, respects the Buddha, and will walk for twelve years (p-30). Some others sought family happiness and better health, or relief from the stress of work, or from retirement.

Mode of transportation in Shikoku pilgrimage: Pilgrims/tourists have several options of travel modes for the Shikoku pilgrimage. These include bus, car, motorbike, scooter, bicycle, and walking. Many of the pilgrims/tourists travel in groups via bus or mini-taxi these days; however, walking is the best way to do the pilgrimage. A significant number of pilgrims - mostly foreigners - still walked the route; however, it does not suit all pilgrims/ tourists depending upon their age, physical situation, time, and desires. Among the five categories of mode of transportation in the Shikoku pilgrimage, the respondents could answer as many as appropriate. The result shows that a majority (52.59\%) of the respondents chose walking, followed by $35.34 \%$ using tourist buses and so on. Furthermore, a cross-tabulation analysis was made between the age groups of the respondents and the mode of travel. The majority $(80 \%)$ of respondents for the $21-40$ age group walked, whereas $44.60 \%$ of the respondents of those aged above 61 were using tourist buses. Younger people preferred walking and travelling individually, whereas the older groups preferred group travel and tourist buses.

Table 3: Cross-tabulation of mode of travels by age-group in Shikoku

\begin{tabular}{|l|l|c|c|c|c|c|c|}
\hline \multirow{2}{*}{ Age group } & \multicolumn{5}{|c|}{ Mode of travels in Shikoku pilgrimage } & \multirow{2}{*}{ Total } \\
\cline { 3 - 8 } \multicolumn{2}{|c|}{} & Walking & $\begin{array}{c}\text { Private } \\
\text { car }\end{array}$ & $\begin{array}{c}\text { Tourist } \\
\text { bus }\end{array}$ & $\begin{array}{c}\text { Motor/ } \\
\text { bicycle }\end{array}$ & Others & \\
\hline \multirow{2}{*}{$21-40$} & Count & 16 & 3 & 4 & 2 & 4 & 20 \\
\cline { 2 - 8 } & $\%$ within age & $80.00 \%$ & $15.00 \%$ & $20.00 \%$ & $10.00 \%$ & $20.00 \%$ & \\
\hline \multirow{3}{*}{$41-60$} & Count & 27 & 10 & 12 & 1 & 6 & 39 \\
\cline { 2 - 8 } & $\%$ within age & $69.20 \%$ & $25.60 \%$ & $30.80 \%$ & $2.60 \%$ & $15.40 \%$ & \\
\hline $\begin{array}{l}\text { Above } \\
61\end{array}$ & Count & 17 & 13 & 25 & 0 & 3 & 56 \\
\cline { 2 - 8 } \\
\cline { 2 - 9 } $\begin{array}{l}\text { Not } \\
\text { mention }\end{array}$ & Count & 1 & 0 & 0 & 1 & 0 & 1 \\
\cline { 2 - 8 } & $\%$ within age & $100.00 \%$ & $0.00 \%$ & $0.00 \%$ & $100.00 \%$ & $0.00 \%$ & \\
\hline Total & Count & 61 & 26 & 41 & 4 & 13 & 116 \\
\hline
\end{tabular}

Organizer of the visit: The respondents were asked about the organizer of their visit. The data shows that a majority of the respondents $(66.4 \%)$ organized their visit themselves, $26.7 \%$ visited with a guided tour, and $4.3 \%$ respondent's visit were organized by others, whereas $2.6 \%$ of the respondents did not mention. 
Stay in Shikoku: Pilgrims/tourists have various options for accommodation during the Shikoku pilgrimage. The respondents were asked about their stay in Shikoku-they could give as many answers as appropriate. A majority of the respondents (83.6\%) stayed in hotels, $54.3 \%$ in temples, $28.4 \%$ in lodges, $29.3 \%$ in other places (such as tents), $4.3 \%$ in the houses of relatives or friends, and $1.7 \%$ did not mention where they stayed. Most pilgrims search for budget-class accommodation. The respondents opined that the hotels in Shikoku are expensive. The lodging should be cheaper ( $\mathrm{p}-13)$, more affordable accommodations that are flexible with arrival time, bath time, meals, and so forth (p-104), and some accommodation places were booked out by bus pilgrims/tourists so there was no space for individual henro (p-24).

Willingness to visit Lumbini: An attempt was made to inquire about willingness to visit Lumbini in Nepal. The result shows that a majority of the respondents $(76.7 \%)$ expressed that they do not want to visit Lumbini, $21.6 \%$ want to visit, and $1.7 \%$ of respondents did not give their opinion. In a cross-tabulation analysis between the nationalities of the respondents and their plans to visit Lumbini, a majority $(87.7 \%)$ of Japanese respondents do not have any plans to visit. On the other hand, $100 \%$ of Italian and $42.9 \%$ of German respondents want to visit Lumbini.

Expectation from Shikoku pilgrimage: "Why do people go and what do they expect from the Shikoku pilgrimage?" is one of the important questions. As noted by one of the respondents (E-3), people have different expectations and they want to gain something from the Shikoku pilgrimage. Other expert respondents opined that Shikoku has a unique culture which is very precious. People go on pilgrimage to reflect on themselves, clear their mind and spirit (E-4), gain worldly benefits and memorials for their ancestors (E-2), and recall old memories and get relief from sickness and the death of parents (E-1). There seems to be a "pilgrimage boom" and people want to try a pilgrimage that is not well known. Some want to experience a lengthy religious journey in Japan, or want to interact with the Japanese in a countryside setting (E-5). One pilgrim respondent said that it changed her as a person, being impressed with the generosity of the people, the peacefulness of the surroundings, and the profoundly surreal way of life that she could have never imagined. It was an experience of a lifetime that she still thinks about today (p-107). Other expectations were to experience the unique culture of Shikoku, improve mental health, for spiritual development, interaction and involvement with the locals, experience Japanese culture, enjoy and reconnect with nature, self-improvement and personal satisfaction, a sense of achievement, discovering things about oneself, deep emotional feelings, a chance to escape everyday life, for a broader understanding of Buddhism, more insight into cultural and religious beliefs in Japan, spiritual comfort, to improve mental and personal health, develop a positive attitude, fulfillment of a wish, and more. P-41 was 
expecting time for reflection upon her life. She wanted to be on her own and to get rid of bad things from the past. She expected to come to terms with her mother's death. It had changed her life, her way of looking at people, and she became a Buddhist. She learned to bear bad weather and still stay positive. Some others expected to learn about history, culture, and Buddhism, tourism and health, or had an interest in gifts and food sold at local shops, or to sleep outside and to remain healthy.

Opinion regarding extended circuit between Lumbini and Shikoku: In response to the question, "What is your opinion regarding an extended Buddhist circuit between Lumbini and Shikoku?", most of the respondents took it as a spectacular idea. They opined that it is good for Buddhists or pilgrimage lovers to have a connection between the Buddha's birthplace from where the Buddhism originated and developed, and Shikoku. People who do pilgrimages are always interested in the next one. Given that the Buddha was born in Lumbini, it is natural that Buddhist pilgrims would love to go there. It could be a long journey of a few weeks combining pilgrimage and tourism. P-68 asked, when can I go? However, most of the people visiting Shikoku are not aware of Lumbini. Many, on the other hand, found the connection between Shikoku and Lumbini very interesting, with possible connections between people from different countries and places, and to connect the two regions and see how Buddhism evolved between South and East Asia. It could be highly interesting for those who want to explore, and for those who want to learn more about Buddhism, and interesting for specific interest groups. It would be a great opportunity for Japanese and people from other countries to know about the place which is the origin of Buddhism, and also to know about Nepal and do pilgrimages. It would be good for Buddhism and both countries, to have a connection between two important Buddhist sites and countries with similar faiths and beliefs. Many Japanese will visit Nepal, and Nepalese will visit Japan. Alternatively, some other respondents asked, how is Lumbini promoted? How can I get information if I want to visit Lumbini? There should be more advertisements internationally, with books, articles, and other resources, as long as it does not become just another reason for a commercial enterprise. Shikoku is basically centered on Kōbō Daishi, and Lumbini is the birthplace of Shakyamuni, so it might be difficult to connect them directly. Japanese and Nepalese have differences in Buddhist culture and tradition, which also might make it difficult to make connections.

Impacts of pilgrimage tourism in Shikoku: Pilgrimage tourism has various impacts in Shikoku. Among them, the economic impact is one of the most important. In an enquiry to identify the economic impacts of pilgrimage tourism in Shikoku, $73.3 \%$ cited that there is an economic impact, $6.8 \%$ stated no, and $19.9 \%$ did not give their opinion. Those who felt the economic impact and replied "yes" were further asked to indicate as many of these as appropriate. Most of the first time visitors and 
foreigners were unsure of the impact. The multiple response output result shows that $90.6 \%$ responded to the consumption of local products, $52.8 \%$ responded to job opportunities, $51.9 \%$ responded to increased communication, and so on.

Further, positive and negative impacts perceived by the respondents are given in the following table.

Table 4: Impacts Perceived by Respondents

\begin{tabular}{|l|}
\hline \multicolumn{1}{|c|}{ Positive } \\
\hline - \\
Meet people from different countries/ \\
-
\end{tabular}

- Employment for local people, buying local products and staying in local facilities by visitors

- Support small business such as accommodation, food etc., must be positive for the local people as it brings much needed income onto the island

- Many accommodation places at short distances

- Respect for other cultures (both ways) and nature

- Better facilities for pilgrims (e.g. henro huts), more jobs in hotels/ other accommodation

- Sense of satisfaction

- Preserve long history of Buddhism, culture and nature of Japan

- Economic and infrastructures development

- Rural areas become more active

- Tourism can impact on spiritual atmosphere

- Increased traffic on small roads

- Mass-tourism can change the feeling of the places and make them unpleasant

- Shikoku people can be intimidated, because it is so crowded in April/ May and October/November

- Perhaps Henro becoming a bit commercialized and many basic rather than spiritual tourists

- It would be destroyed by mass tourism

- Garbage and environmental problem

- Interfere with local society and culture

- During the busy seasons there are so many pilgrimage bus tours and the temple grounds and temple office can get quite crowded making it difficult to enjoy the usual serenity of each sacred site. As well, the focus is turned towards the masses and not the walking pilgrims. There is always a problem of parking lot size, noise from traffic, garbage, the need for large washrooms etc. 


\begin{tabular}{|l|l|}
\hline $\begin{array}{l}\text { Local communities' involvement in } \\
\text { tourism }\end{array}$ & $\begin{array}{l}\text { - The teaching of Buddhism are not } \\
\text { being transmitted } \\
\text { - }\end{array}$ \\
& Language problem to the foreigners \\
- Ifinditvery sadthatthe Japanesein their \\
amazing generosity and eagerness to \\
please, feel they must adapt and change \\
ancient customs to attract westerners/ \\
non-Japanese to what is inherently a \\
Buddhist/Japanese pilgrimage. I love \\
Japan and the Japanese culture with \\
a passion and have been coming to \\
Japan since 1977 (over 20 times) and \\
do not want to see Japan trying to be \\
more like the westerners / especially \\
like the Americans. It can only harm \\
the beautiful Japanese culture and \\
ways (p-78)
\end{tabular}

\section{Problems in and around} Shikoku: The pilgrims/tourists will be satisfied with the visit, enjoy their trip, and might repeat their visit if they have no problem at that destination. The tourism providers should work carefully to minimize problems. The respondents were asked whether they had problems in Shikoku or not. The majority

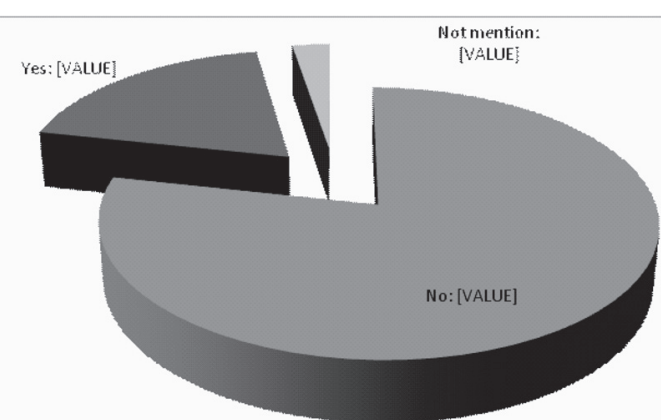

Figure 2: Problem in Shikoku of the respondents $(78.4 \%)$ stated that there were no problems; however, $19 \%$ of the respondents experienced different problems in Shikoku and $2.6 \%$ of the respondents were unable to give their opinion. Furthermore, the respondents were asked to state their problems during the Shikoku pilgrimage. P-78 explains that "as a Western woman people tended to turn me away rather than treat me differently to how they think I should be treated. I was often told at temples there was no accommodation (when I knew there was). I would get Japanese people to make the calls to the temples and some ryokans on my behalf to make a booking and very often - at least once a week! — there would be availability, until they hear my name and learn that I am a westerner and a woman-then I am told no availability, we 
are full!" Problems faced by other pilgrims were signs for non-Japanese readers/ speakers, hard-to-read menus, labels, and name as they were basically in Japanese, and irregular public transportation.

In answer to the question, "What are the weaknesses to develop pilgrimage tourism?" (E-5) explains that there needs to be a balance between "pilgrimage" and "tourism." If things become too touristy, then the religious or spiritual side of the pilgrimage disappears. Some foreigners have mentioned that they do not want to see the Shikoku pilgrimage turn into a Disneyland type of place. (E-6) emphasizes that temples and the temple association need to make a concerted effort to make the walk easier for walking non-Japanese pilgrims. Lodging issues, places to sit out of the rain at temples, and so forth are important. I believe that there is a general lack of concern for non-Japanese pilgrims. The temples want the numbers to increase, but no one is trying to make life easier for them. Likewise, it should be a spiritual journey to fulfill pilgrims' desires (E-3), and many travel agencies are interested only in profit (E-2). There is no official policy; most of the development is from individual interest (E-3), and young people have insufficient knowledge (E-1). (E-5) further recommends having a "Cultural/Historical Center" for the Shikoku pilgrimage near Temple 1. Many of the respondents recommended various strategies to improve Shikoku pilgrimage/tourism such as development of English Language materials, multi-lingual signs, English speakers at hotels and temples, Timetables at the bus and train stops and stations. Lodging should be cheaper, flexible with arrival time, bath time, meals etc., making it more accessible to walking pilgrims with cheaper hotels like Santiago's way..., luggage store in Tokushima for foreigners, more access to DATA and PHONE sim for short term. However, there are few voices against commercialization and bringing UNESCO something in Shikoku that could burn Shikoku out with rampant tourism. Do not kill the 'pilgrimage' spirit, culture and tradition. Reduce garbage and improve services to cater larger number of pilgrims/ tourists in the days to come.

\section{Benefit of heritage tourism}

Heritage tourism protects historic, cultural, and natural resources in towns and cities by involving people in their community. When they can relate to their personal, local, regional, or national heritage, people are more often motivated to safeguard their historic resources. Heritage tourism educates residents and visitors about local and regional history and shared traditions. Through involvement and exposure to local historic sites, residents become better informed about their history and traditions. Understanding the importance of one's heritage provides continuity and context for a community's residents, and it strengthens citizenship values, builds community pride, and improves quality of life. When a community's heritage is at the core of what you offer visitors, it is essential to protect that heritage. One has to make sure 
that increased tourism does not destroy the very qualities that attracted tourists in the first place. Tourism has an impact on the resources and puts stress and strain on infrastructure such as roads, airports, water supplies, and public services. By protecting the historic landmarks and places, unique qualities, and special traditions that attract visitors, you are safeguarding these resources, and the future and vitality of your community (Speno, 2010). Tourism became the method by which the heritages could be commodified. In the hopes of halting rural out-migration and increasing visits to rural areas, the central government encouraged rural villages to recreate the furusato (lit. old village) or native place ideal for tourists and encouraged tourists to reconnect with their rural past by visiting such places in Japan (McMorran, 2008). It is argued that heritage has a value far beyond the price that can be put on it; a cultural value to society, both present and future, which one must not allow to become compromised by base commercial values (Garrod \& Fyall, 2000). Heritage has been protected for over a thousand years in Japan. Shoso-in, the first museum in Japan, dates back to the 8th century; it is an Imperial storehouse aTodai-ji temple and a designated national treasure (included in the World Heritage List), which contains many artifacts and books from the Nara era (8th century). Many precious artifacts, buildings, and other valuable items throughout Japan have been protected by stakeholders for a variety of purposes: religious, educational, and social (Kakiuchi, 2014).

\section{Matter of discussion}

Cultural heritage plays an important role as a reflection of cultural, historical, and social values, and is often crucial for sustainable development. Cultural heritage is understood to be valuable to national and community identities, links to the past, and ongoing social cohesion. But cultural heritage is also important in promoting economic development and can play a key role in growth and poverty reduction; it can also contribute to sustainable development and to the resilience of communities and societies. To protect lives, livelihoods, and cultural heritage, it is important to strengthen the resilience of assets at risk and make disaster resilience an intrinsic part of cultural heritage management. Ongoing practice and lessons learned can help inform broader approaches to resilience for countries whose heritage assets are highly exposed to natural hazards. Multi-hazard risk and vulnerability assessments and multidisciplinary studies of heritage sites should be conducted on a periodic basis for a better understanding of risks and more effective risk mitigation investments and planning. It is important to build the capacity of government and other stakeholders for identification and monitoring of risks, risk reduction and response to disasters, and recovery and restoration efforts. Community engagement in disaster risk management is of great significance. Networks of professionals trained in risk identification, risk reduction, post-disaster recovery, and preservation of cultural heritage should be formed. In addition, agencies should be encouraged 
to collaborate with academia to promote research in this area. In Japan, the work of the Institute of Disaster Mitigation for Urban Cultural Heritage at Ritsumeikan University (R-DMUCH) is recognized globally for its training of professionals across the world, and for its knowledge-sharing and capacity building efforts in Japan and beyond (WBG, 2017).

It has been interesting lesson to rest of the world how Japan has been mitigating and surviving with large scale disasters. The Japanese culture, tradition and technology must have been playing significant role for this. In response to that humanitarian crisis, it is learnt that the recovery effort was prompt in Japan. The repair and restoration of built heritage has proved to be an important social element for communities recovering from disaster. Local advocates formed a coalition to catalog the damage and coordinate domestic and international aid for the rehabilitation of cultural heritage. Local authorities in Japan have been prioritizing the needs of different sites and communities affected by the disasters. The work in affected area aimed to help reinvigorate the local economy and boost town morale by rebuilding the tourist economy. Each year visitor rates continued to grow, and substantial funds had been raised to continue assisting local residents and business owners in their recovery efforts. On the other hand, it has been more than three years that the devastating earthquake in 2015 had damaged the cultural heritages of Kathmandu valley. The temples and palaces at the world's largest concentration of UNESCO World Heritage Sites remain heaps of rubble, other structures that had suffered seismic damage were still being propped up by wooden beams, and a very little reconstruction has taken place. The earthquake-damaged world heritage sites in Kathmandu Valley are at risk of being put on the UNESCO list of World Heritage in DANGER if they are not renovated/preserved within a given time. Likewise, another cultural heritage Lumbini is also facing many problems as the Lumbini Master Plan has not been completed on time. There are problems at natural heritages as well. Heritage tourism has great prospects in Nepal. The country can benefit a lot from it and the learning from Japan could be instrumental to manage, rebuild and develop heritage sites and tourism in Nepal.

\section{Conclusion}

Japan and Nepal's remarkable heritage is not only part of what makes both the countries a popular travel destination, but also something that needs to be properly protected, maintained and preserved, so that future generations can enjoy it as much as we do today. Both Japan and Nepal have to be very optimistic about the future of tourism, particularly in heritage as it has huge potentials to be the top class tourist destinations. Tourists can experience, enjoy and feel the difference with diverse tourist attractions, unique cultures, history and religion in Japan and Nepal. Specially, Nepal can have multiple benefits from tourism. Tourists visiting means directly helping 
rebuilt the country. Their contribution means a lot to boost up the tourism activities and economy, transform the best technology and practices to the needy ones. A wellpreserved heritage enables communities to learn about their cultural history truly and chronologically. Cultural tourism creates jobs and new business opportunities and strengthens local economy. Heritage tourism helps also to protect cultural heritage and to improve the quality of life of residents and visitors. Linking tourism with heritage and culture will benefit the local economy. The main idea in cultural heritage tourism is to save urban heritage and culture, to share it with visitors, and to reach economic benefits.

\section{References}

Ambros, B. (1997). Liminal journeys: Pilgrimages of noblewomen in mid-Heian Japan. Japanese Journal of Religious Studies, 24/3-4: 301-45.Barber, R. (1993). Pilgrimages. London: The Boydell Press.

Collins-Kreiner, N.; Kliot, N.; Mansfeld, Y. \& Sagi, K. (2006). Christian Tourism to the Holy Land Pilgrimage during security Crisis, New York: Routledge.

EJN (2018). Embassy of Japan in Nepal. (Retrieved from: http://www.np.emb-japan. go.jp/itpr_en/japan_nepal.html).

Evans, G. (1998). Mementos to take home: The ancient trade in souvenirs. In Search of Heritage: As Pilgrim or Tourist? (ed.) J. Fladmark, Dorset: Donhead Publishing.

Garrod, B. \& Fyall, A. (2000). Managing Heritage Tourism. Annals of Tourism Research, 27 (3): 682-708.

Ghimire, H.L. (2017). Buddhist Pilgrimage: A Comparison of Lumbini and Shikoku. Bulletin. Nagoya: Nanzan Institute for Religion \& Culture, 41: 21- 55.

Ghimire, H.L. (2016). Disaster Management and Post-quake Impact on Tourism in Nepal. THE GAZE Journal of Tourism and Hospitality. Kathmandu: International School of Tourism and Hotel Management (Affiliated to Salzburg University of Applied Sciences, Austria), 7 (1): 37-57.

Ghimire, H. L. (2013). Impacts of Pilgrimage Tourism for Sustainable Tourism Development: Special Focus on Lumbini. Kathmandu: Central Department of Statistics, Tribuuvan University (PhD Thesis).

Ghimire, H. L. \& Rai, H.D. (2015). Spirituality in Lumbini: A fundamental aspect of Buddhism. Lumbini Darpan. Lumbini: Lumbini Development Trust.

Ghimire, H.L. \& Upreti, R. (2017). Kenzo Tange's Master Plan and Spirituality in Lumbini, Nepal. Discussions for Sustainable Development and Culture-Lessons for and from Emerging Asia (The Proceedings for the 1st International Forum). Nagoya: Faculty of Foreign Studies, Meijo University. 
Guruge, A. W.P. (1998). Buddhist Philosophy and World Peace. In Vaidya \& Khatri (Eds). Proceedings of the World Buddhist Summit. Lumbini: HMG/N and Lumbini Development Trust.

Hoelscher, S. (2006). Heritage. MacDonald, S. (ed.) A Companion to Museum Studies, Oxford: Blackwell Publishing.

Iannarone, M. (2013). O-henro: Walking the pilgrimage of 88 temples in Shikoku. Tokyo Weekender Japan's Premier English Magazine(Retrieved from: http://www.tokyoweekender. com/2013/12/o-henro-walking-the-pilgrimage-of-88-temples-in-shikoku/).

Jamieson, W. (1998). Cultural Heritage Tourism Planning and Development: Defining the Field and Its Challenges. APT Bulletin, 29 (3-4): 65-67.

JNTO (2018). World Heritage Sites in Japan (Retrieved from: https://www.seejapan. co.uk/where-to-go/traditional/world-heritage-sites-in-japanhttps://www. seejapan.co.uk/press-releases/consumer/2018/01/24/jnto-announces-recordbreaking-visitor-numbers-for-2017-consumer)

Kakiuchi, E. (2014). Cultural heritage protection system in Japan: current issues and prospects for the future. GRIPS Discussion Paper. Tokyo: National Graduate Institute for Policy Studies.

Kunwar, R. R. (2017). Tourists and Tourism (Revised and enlarged edition). Kathmandu: International School of Tourism and Hotel Management.

Kunwar, R. R. \& Ghimire, H.L. (2012). Lumbini as International Pilgrimage Destination : Authenticity and Significance published in THE GAZE Journal of Tourism and Hospitality. Kathmandu: International School of Tourism and Hotel Management, 4 (1): 1-33

Kunwar, R.R. \& Chand, U. (2016). Natural Disaster and Heritage Tourism: A Study on the Impacts of Earthquake in Bhaktapur, Nepal. Journal of Tourism and Hospitality, 6:1-39

MacGregor, F. (2002). Shikoku Henro A study of Japanese and western pilgrims on the Shikoku Eighty-Eight Sacred Places Pilgrimage. Faculty of Social Studies, School of East Asian Studies, The University of Sheffield (A dissertation for the MA).

McMorran, C. (2008). Understanding the 'Heritage' in Heritage Tourism: Ideological Tool or Economic Tool for a Japanese Hot Springs Resort? Tourism Geographies, 10 (3): 334-354 (Retrieved from: http://profile.nus.edu.sg/fass/jpscmm/2008\%20 mcmorran\%20heritage.pdf).

Moreton, D. C. (2016). Personal interview and responses on expert's questionnaire at Tokushima (E-5).

MoCTCA (2018). Nepal Tourism Statistics. Kathmandu: Ministry of Culture, Tourism $\&$ Civil Aviation. 
Murai, S. (2016). Japan's tourism sector evolving but needs more work, cultural heritage expert says. thejapantimes (Retrieved from: https://www.japantimes. co.jp/news/2016/05/04/national/japans-tourism-sector-evolving-needs-workcultural-heritage-expert-says/\#.W0x4wi17H0c).

Pedersen, A. (2002). Managing Tourism at World Heritage Sites: a Practical Manual for World Heritage Site Managers. Paris: UNESCO World Heritage Centre (Retrieved fro: http://whc.unesco.org/uploads/activities/documents/activity-113-2.pdf).

Pye, M. (2014). Japanese Buddhist Pilgrimage. Sheffield: Equinox Publishing.

Reader, I. (1987). From asceticism to the package tour: The pilgrim's progress in Japan. Religion, 17/2: 133-48.

Reader, I. (2005). Making Pilgrimages: Meaning and Practice in Shikoku. Honolulu: University of Hawai'i Press.

Reader, I. (2012). Buddhism, the Shikoku pilgrimage, and wandering saints in Japan. Dharma World (January-March). www.rk-world.org/dharmaworld/ dw_2012janmarshikokupilgrimage.aspx

Reader, I. \& Swanson, P.L. (1997). Editors' introduction: Pilgrimage in the Japanese religious tradition. Japanese Journal of Religious Studies, 24/3-4: 225-70.

San, C. K. (2002). Buddhist Pilgrimage. Malaysia: Subang Jaya Buddhist Association.

Schumacher, M. (2013). Resource Guide Japanese Pilgrims and Pilgrimages. Japanese Buddhist Statuary. (www.onmarkproductions.com/html/pilgrimages-pilgrimsjapan.html).

Speno, L. (Ed.) (2010). Heritage Tourism Handbook: A How to Guide for Georgia (Retrieved from: http://www.georgia.org/wp-content/uploads/2013/09/GAHeritage-Tourism-Handbook.pdf).

Statler, O. (1983). Japanese Pilgrimage. New York: William Morrow and Company, Inc.

Štefko, R.; Királováb, A. \& Mudríka, M. (2015). Strategic Marketing Communication in Pilgrimage Tourism. Procedia - Social and Behavioral Sciences, 175: 423 - 430 (Retrieved from: http://www.sciencedirect.com/science/article/pii/ S1877042815012793).

Sugio, K. (2015). Large-scale Disasters on World Heritage and Cultural Heritage in Japan: Significant Impacts and Sustainable Management Cases, Landscape Research, 40 (6): 748-758.

Swanson, P. L. (1981). Shugendo and the Yoshino-Kumano pilgrimage: An example of mountain pilgrimage. Monumenta Nipponica, 36/1: 55-84. 
Swanson, P. L. (2005). Science, kokoro, and religion: Thoughts on a new project. Bulletin of the Nanzan Institute for Religion and Culture, 29: 20-26. https://nirc. nanzan-u.ac.jp/n le/1956

Szostak, J. (2007). Pilgrims' Process. (Retrieved from http://www.thebuddhadharma. com/TKP (2018). NEPAL AIRLINES TO RESUME JAPAN SERVICE IN SEPT. KATHMANDU: THE KATHMANDU POST (TKP).

UNESCO (2018). https://whc.unesco.org/en/statesparties/jp

WBG (2017). Promoting Disaster Resilient Cultural Heritage. Knowledge Note. World Bank Group (WBG) (Retrieved from: http://documents.worldbank.org/curated/ en/6960615118 82383371/pdf/121709-WP-P161985-PUBLIC-DisasterResilient CulturalHeritageKnowledgeNoteENWEB.pdf)

WTTC (2018). Travel and Tourism Economic Impact 2018 (Retrieved from: https:// www.wttc.org

Yasuda, H. (2010). World heritage and cultural tourism in Japan. International Journal of Culture, Tourism and Hospitality Research, 4 (4): 366 - 375 (link: http://dx.doi. org/10.1108/17506181011081532).

https://en.wikipedia.org/wiki/List_of_destroyed_heritage\#Japan.

http://www.buddhanet.net/e-learning/buddhistworld/about-pilgrim.htm (retrieved on 30 May 2012). 